\title{
Analisis Indeks Kepuasan Masyarakat dan Peramalan Pendapatan Laboratorium Pengujian PPSDM Migas Menggunakan Metode Arima Box-Jenkins
}

\author{
Reni Junita', Eva Khuzaifah ${ }^{2}$ \\ 1 Universitas Diponegoro, Semarang \\ 2Pusat Pengembangan SDM Minyak dan GasBumi, Cepu
}

\begin{abstract}
Abstrak mengalami peningkatan atau penurunan dengan menggunakan metode peramalan analisis runtun waktu.

Analisis Indeks Kepuasan Masyarakat (IKM) bertujuan untuk mengetahui tingkat kinerja unit pelayanan pengguna jasa di lingkungan PPSDM Migas secara berkala dengan melakukan pembagian angket Indeks Kepuasan Masyarakat (IKM) kepada pengguna jasa. Angket IKM ini dibagikan pada setiap peserta untuk setiap penyelenggaraan pengguna jasa di lingkungan PPSDM Migas, sehingga perlu diketahui validitas dari angket tersebut.
\end{abstract}

PPSDM Migas sebagai Badan Layanan Umum memberikan jasa pelayanan kepada masyarakat, salah satunya adalah Jasa Laboratorium. Laboratorium Pengujian merupakan salah satu laboratorium di PPSDM Migas dimana pendapatan yang diperoleh dari jasa tersebut diharapkan sesuai dengan target kinerja yang sudah diharapkan. Dari penelitian ini diharapkan pendapatan yang diperoleh di Laboratorium Pengujian PPSDM Migas dapat diketahui akan

Kata kunci: peramalan, validitas, realibilitas

INFORMASI NASKAH

Diterima: 18 Pebruari 2021

Direvisi: 24 Maret 2021

Diterima: 31 Maret 2021

Terbit: 24 April 2021

Email korespondensi: renijunita05@gmail.com

Laman daring:

https://doi.org/10.37525/ $\mathrm{sp} / 2021-1 / 276$

\section{Pendahuluan}

Laboratorium Pengujian PPSDM Migas memberikan pelayanan pengujian, sesuai dengan laboratorium yang tersedia di laboratorium pengujian. Pada Laboratorium Minyak Bumi diberikan layanan pengujian terhadap sifat-sifat fisik minyak bumi dan produknya yang meliputi bensin, minyak solar, BBM Penerbangan, petroleum, solvent, dan pelumas. Pada Laboratorium Kimia dan Lindungan Lingkungan pengguna jasa dapat mengajukan pengujian terutama terkait dengan sifat-sifat kimia minyak dan gas bumi. Selain itu, Laboratorium Eksplorasi dan Eksploitasi melayani pengujian terutama terkait Eksplorasi dan Eksploitasi minyak dan gas bumi. Pengujian terkait dengan Pekerjaan Konstruksi Bangunan dan Jalan dilaksanakan oleh Laboratorium Teknik Sipil. 
Suatu data atau informasi yang digunakan untuk mengukur tingkat kepuasan masyarakat adalah Indeks Kepuasan Masyarakat. Dalam hal ini PPSDM MIGAS membagikan kuisioner agar memperoleh Indeks Kepuasan Masyarakt terhadap pelayanan yang ada pada Laboratorium Pengujian. Pembuatan kuisioner tersebut didasari oleh Peraturan Menteri Pendayagunaan Aparatur Negara dan Reformasi Birokrasi Republik Indonesia Nomor 14 Tahun 2017 tentang Pedoman Penyusunan Survei Kepuasam Masyarakat Unit Penyelenggara Pelayanan Publik. Dalam penyusunan kuisioner, terdapat Sembilan komponen yang harus diperhatikan yaitu Persyaratan, Sistem/Mekanisme/Prosedur, Waktu Penyelesaian, Biaya/tarif, Produk Spesifikasi Pelayanan, Kompetensi Pelaksana, Perilaku Pelaksana, Penanganan Pengaduan/Saran/Masukan, serta Sarana dan Prasarana.

\section{Tinjauan Pustaka}

\section{A. Peramalan (Forecasting)}

Peramalan (Forecasting) adalah suatu teknik untuk memperkirakan suatu nilai pada masa yang akan datang dengan memperhatikan data masa lalu maupun data saat ini (Aswi dan Sukarna, 2006). Dengan mempelajari teknik ini, belum tentu dapat meramal apa saja dengan tepat. Sehingga perlu dipertimbangkan teknik peramalan tertentu yang dapat diaplikasikan pada situasi tertentu juga.

Berdasarkan Heizer and Render (1999), kategori pengelompokkan jangka waktu peramalan dapat, adalah sebagai berikut:

- Jangka pendek, yaitu peramalan untuk jangka waktu kurang dari tiga bulan.

- Jangka menengah, yaitu peramalan untuk jangka waktu antara tiga bulan sampai tiga tahun.

- Jangka panjang, yaitu peramalan untuk jangka waktu lebih dari tiga tahun.

\section{Identifikasi Model Runtun Waktu Box-Jenkins}

Menurut Wei (2006), penetapan model ARIMA sementara (tentative) dilakukan dengan menentukan nilai $\mathrm{p}, \mathrm{d}$ dan $\mathrm{q}$. Nilai $\mathrm{p}$ merupakan orde untuk proses autoregresif, $d$ merupakan orde differencing dan q merupakan orde untuk proses moving average. Dalam menetapkan nilai p dan q dapat dibantu dengan mengamati pola Autocorrelation Function (ACF) dan Partial Autocorrelation Function (PACF). Secara teoritis, karakteristik dari ACF dan PACF untuk proses stasioner $A R(p), M A(q)$ dan $\operatorname{ARMA}(p, q)$ ditunjukkan seperti Tabel 3.

Tabel 1. Tabel Karaketeristik ACF dan PACF

\begin{tabular}{|c|c|c|}
\hline Proses & ACF & PACF \\
\hline AR $(p)$ & $\begin{array}{c}\text { Turun secara eksponensial atau memben- } \\
\text { tuk gelombang sinus }\end{array}$ & Terputus pada lag $p$ \\
\hline
\end{tabular}




\begin{tabular}{|c|c|c|}
\hline MA $(q)$ & Terputus pada lag $q$ & $\begin{array}{c}\text { Turun secara eksponensial atau mem- } \\
\text { bentuk gelombang sinus }\end{array}$ \\
\hline $\operatorname{ARMA}(p, q)$ & Terputus pada lag (q-p) & Terputus pada lag $(p-q)$ \\
\hline
\end{tabular}

\section{Model Autoregresif (AR)}

Model AR yaitu nilai sekarang suatu proses yang dinyatakan sebagai jumlah tertimbang nilainilai $p$ yang lalu ditambah dengan sebuah residual acak sekarang. Dalam hal ini $a_{t}$ diasumsikan independen dan berdistribusi normal dengan rata-rata 0 dan varian konstan $\sigma_{a}^{2}$, atau dapat ditulis $a_{t} \sim N\left(0, \sigma_{a}^{2}\right)$. Soejoeti (1987) menetapkan bahwa, bentuk umum proses autoregresif tingkat $\mathrm{p}$ adalah:

$$
Z_{t}=\phi_{1} Z_{t-1}+\phi_{1} Z_{t-2}+\cdots+\phi_{p} Z_{t-p}+a_{t}
$$

Dengan,

$Z_{t}$ : nilai variabel pada waktu ke-t

$\mathrm{Z}_{\mathrm{t}-1}, \mathrm{Z}_{\mathrm{t}-2,}, \ldots, \mathrm{Z}_{\mathrm{t}-\mathrm{p}}$ : nilai masa lalu dari time series yang bersangkutan pada waktu $\mathrm{t}-1, \mathrm{t}-2, \ldots, \mathrm{t}-\mathrm{p}$ $\phi_{p}:$ koefisien regresi, $\mathrm{i}=1,2,3, \ldots, \mathrm{p}$

$a_{t}$ : nilai error pada waktu ke $-\mathrm{t}$

Dari persamaan di atas dapat ditulis dengan:

$$
\phi(B) Z_{t}=a_{t}
$$

dengan,

$\phi(B)=1-\phi_{1} B-\phi_{2} B^{2}-\cdots-\phi_{p} B^{p}$ dinamakan operator AR(p). B merupakan operator langkah mundur (backshift operator), yaitu $B\left(Z_{t}\right)=Z_{t-1}$.

\section{Model Moving Average (MA)}

Berdasarkan Wei (2006), bentuk umum proses Moving Average tingkat q adalah: $Z_{t}=a_{t}-\theta_{1} a_{t-1}-\cdots-\theta_{p} a_{t-q}$ dengan, 
$\mathrm{Z}_{\mathrm{t}}$ : nilai variabel pada waktu ke-t

$a_{t}, a_{t-1}, a_{t-2}, \ldots, a_{t-q}:$ nilai error pada waktu $\mathrm{t}, \mathrm{t}-1, \mathrm{t}-2, \ldots \mathrm{t}-\mathrm{q}$

$\theta_{i}:$ koefisien regresi, $\mathrm{i}=1,2,3, \ldots, \mathrm{p}$

dimana $a_{t}$ independen dan berdistribusi dengan mean 0 dan varian konstan $\sigma_{a}^{2}$. Persamaan dapat ditulis:

$Z_{t}=\theta(B) a_{t}$

dengan $\theta(B)=1-\theta_{1} B-\theta_{2} B^{2}-\cdots-\theta_{q} B^{q}$ adalah operator $\mathrm{MA}(\mathrm{q})$. Persamaan tersebut dapat

ditulis:

$\theta^{-1}(B) Z_{t}=a_{t}$

Atau dapat ditulis:

$Z_{t}-\pi_{1} Z_{t-1}-\pi_{2} Z_{t-2}-\cdots=a_{t}$

\section{Model Autoregressive Moving Average $(\operatorname{ARMA}(p, q))$}

Menurut Makridakis et al. (1999), suatu perluasan yang dapat diperoleh dari model AR dan MA adalah model campuran ARMA $(p, q)$ yang berbentuk:

$Z_{t}=\phi_{1} Z_{t-1}+\phi_{2} Z_{t-2}+\cdots+\phi_{p} Z_{t-p}+a_{t}-\theta_{1} a_{t-1}-\cdots-\theta_{q} a_{t-q}$

dengan,

$a_{t}, a_{t-1}, a_{t-2}, \ldots, a_{t-q}$ : nilai error pada waktu $\mathrm{t}, \mathrm{t}-1, \mathrm{t}-2, \ldots \mathrm{t}-\mathrm{q}$

$\theta_{i}:$ koefisien regresi, $\mathrm{i}=1,2,3, \ldots, \mathrm{p}$

$\mathrm{Z}_{\mathrm{t}-1}, \mathrm{Z}_{\mathrm{t}-2}, \ldots, \mathrm{Z}_{\mathrm{t}-\mathrm{p}}$ : nilai masa lalu dari time series yang bersangkutan pada waktu $\mathrm{t}-1, \mathrm{t}-2, \ldots, \mathrm{t}-\mathrm{p}$ $\phi_{p}:$ koefisien regresi, $\mathrm{i}=1,2,3, \ldots, \mathrm{p}$

dimana $a_{t}$ independen dan berdistribusi dengan mean 0 dan varian konstan $\sigma_{a}^{2}$. Persamaan dapat ditulis:

$\phi(B) Z_{t}=\theta(B) a_{t}$

dimana $\phi(B)=1-\phi_{1} B-\cdots-\phi_{p} B^{p}$ dan $\theta(B)=1-\theta_{1} B-\cdots-\theta_{q} B^{q}$ agar proses menjadi stasioner dan invertible, maka akar $\theta(B)=0$ dan $\phi(B)=0$ haruslah terletak pada luar lingkaran satuan. 


\section{Autoregressive Integrated Moving Average (ARIMA)}

Proses $\operatorname{ARIMA}(\mathrm{p}, \mathrm{d}, \mathrm{q})$ ini merupakan model runtun waktu yang nonstasioner. Menurut Wei (2006), model dari ARIMA $(p, d, q)$ adalah :

$\phi_{p}(B)(1-B)^{d} Z_{t}=\theta_{q}(B) a_{t}$

dimana $\phi_{p}(B)$ adalah operator proses $\mathrm{AR}(\mathrm{p})$ dan $\theta_{q}(B)$ adalah operator proses MA(q) sehingga diperoleh persamaan sebagai berikut:

$\phi_{p}(B)=1-\phi_{1} B-\phi_{2} B^{2}-\cdots-\phi_{p} B^{p}$

$\theta_{q}(B)=1-\theta_{1} B-\theta_{2} B^{2}-\cdots-\theta_{q} B^{q}$

Proses ARIMA $(p, d, q)$ dapat dinyatakan dalam bentuk observasi yang lalu dan sesatan random yang lalu dan sekarang, untuk $d=1$, diperoleh:

$$
\begin{gathered}
Z_{t}=\left(1+\phi_{1}\right) Z_{t-1}+\left(\phi_{2}-\phi_{1}\right) Z_{t-2}+\left(\phi_{3}-\phi_{2}\right) Z_{t-3}+\ldots+\left(\phi_{p}-\phi_{p-1}\right) Z_{t-p}-\phi_{p} Z_{t-p-1} \\
+a_{t}+\theta_{1} a_{t-1}+\ldots+\theta_{q} a_{t-q} \\
\text { yang dikenal dengan } \operatorname{ARIMA}(p, 1, q) .
\end{gathered}
$$

Sebagai contoh model $\operatorname{ARIMA}(1,1,1)$ mempunyai bentuk:

$Z_{t}=\left(1+\phi_{1}\right) Z_{t-1}-\phi_{1} Z_{t-2}+a_{t}+\theta_{1} a_{t-1}$

yang kelihatan seperti $\operatorname{ARMA}(2,1)$ dengan $" \phi_{1} "=1+\phi_{1}$ dan $" \phi_{2} "=\phi_{1}$ dan tidak memenuhi syarat stasioneritas.

Demikian juga bentuk $A R I M A(0,1,1)$ atau $\operatorname{IMA}(1,1)$ :

$$
Z_{t}=Z_{t-1}+a_{t}+\theta_{1} a_{t-1}
$$

yang kelihatan seperti $\operatorname{ARMA}(1,1)$ nonstasioner dengan $\phi_{1}=1$.

\section{B. Uji Validitas dan Reliabilitas}

Uji validitas dan reliabilitas diperlukan pada saat melakukan sebuah pengujian atau pengukuran yang digunakan sebagai bagian dari proses pengumpulan data. Data dalam suatu penelitian ilmiah dapat diperoleh dari berbagai macam metode, diantaranya adalah kuesioner. Penggunaan angket sebagai alat pengumpul data tentunya telah disertai dengan berbagai macam per- 
timbangan, dan sebagai alat ukur dalam penelitian, kuesioner harus memenuhi kriteria tertentu sehingga dapat memberikan informasi yang tepercaya, yaitu harus mempunyai validitas dan realibilitas yang baik. Validitas dan realibilitas yang baik diperlihatkan oleh tingginya validitas dan reliabilitas hasil ukur suatu pengukuran.

Suatu alat uji ukur yang tidak valid dan reliabel akan memberikan informasi yang tidak akurat mengenai keadaan subject/ responden/individu yang dikenai pengukuran/tes tersebut. Penggunaan informasi yang salah sebagai dasar pengambilan suatu kesimpulan dan keputusan, maka tentu saja kesimpulan dan keputusan tersebut akan menjadi tidak tepat.

\section{Uji Validitas}

Uji validitas perlu dilakukan untuk menguji sejauh mana ketepatan atau kebenaran suatu instrumen sebagai alat ukur variabel penelitian. Alat ukur yang digunakan valid atau benar maka hasil pengukuran pun pasti akan benar, atau dengan kata lain, validitas berbicara tentang bagaimana suatu alat ukur yang digunakan memang telah mengukur apa yang ingin diukur. Suatu angket yang memuat pertanyaan tidak jelas bagi responden termasuk tidak valid. Pengujian validasi biasanya menggunakan teknik korelasi. Pengukuran korelasi yang dilakukan adalah korelasi antara skor tiap atribut/variabel/pernyataan dan total penyusun atribut/variabel/ pernyataan yang digunakan.

- Hipotesis

$\mathrm{H}_{0}$ : Butir pertanyaan tidak valid

$\mathrm{H}_{1}$ : Butir pertanyaan valid

- Statistik Uji

$r=\frac{\sum(x-\bar{x})(y-\bar{y})}{\sqrt{\sum(x-\bar{x})^{2}} \sqrt{\sum(y-\bar{y})^{2}}}=\frac{\sum x y-\left(\sum x\right)\left(\sum y\right) / n}{\sqrt{\sum x^{2}\left(\sum x\right)^{2} / n} \sqrt{\sum y^{2}\left(\sum y\right)^{2} / n}}$

- Daerah Kritis

$\mathrm{H}_{0}$ ditolak apabila nilai sig $<$ taraf signifikansi $(\alpha)$.

\section{Uji Reliabilitas}

Uji reliabilitas merupakan suatu pengujian yang berorientasi pada derajat stabilitas, konsistensi, daya prediksi, dan akurasi. Uji realibilitas dilakukan untuk melihat kesesuaian nilai dari sebuah kuesioner yang dikerjakan oleh seorang responden pada kesempatan atau waktu yang berbeda dan dengan kuesioner yang sama. Untuk menunjukkan sejauh mana pengukuran tersebut dilakukan secara baik atau bebas dari error, sehingga memberikan jaminan bahwa data hasil pengukuran tersebut konsisten meskipun dalam waktu yang berbeda, sehingga diperlukan uji realibilitas. Indikasi mengenai stabilitas dan konsistensi pada suatu pengukuran dapat dilihat pada keandalannya.

- Hipotesis

$\mathrm{H}_{0}$ : Atribut/variabel/pernyataan tidak menghasilkan pengukuran yang konsisten. 
$H_{1}$ : Atribut/variabel/pernyataan menghasilkan pengukuran yang konsisten.

- $\quad$ Statistik Uji

- Rumus Spearman Brown

Butir-butir instrumen/pertanyaan dibagi menjadi dua bagian (split-half), yaitu pertanyaan ganjil dan genap sesuai nomor urut.

$$
r_{11}=\frac{2 \cdot r_{1 / 2.1 / 1}}{1+2 \cdot r_{1 / 2.1 . / 1}}
$$

\section{Keterangan :}

$r_{11}=$ reliabilitas instrumen

$r_{1 / 2.1 / 1}=$ korelasi antar dua belahan kuisioner.

○ Rumus Flanagan

Kuisioner dilakukan belahan dua, seperti Spearman-Brown.

$r_{11}=2\left(1-\frac{V_{1}-V_{2}}{V_{t}}\right)$

Keterangan :

$\mathrm{V}_{1}$ : Ragam belahan pertama (ganjil)

$\mathrm{V}_{2}$ : Ragam belahan kedua (genap)

$\mathrm{V}_{\mathrm{t}}$ : Ragam total pertanyaan.

○ Rumus Rulon

$r_{11}=1-\frac{V_{d}^{\prime} \text { lakukan belahan dua. }}{V_{t}}$

Keterangan :

$\mathrm{V}_{\mathrm{d}}$ : Ragam beda (dihitung dari selisih skor belahan ganjil dan belahan genap)

$\mathrm{V}_{\mathrm{t}}$ : Ragam total pertanyaan

○ Rumus Alpha

$$
r_{11}=\left[\frac{k}{k-1}\right]\left[1-\frac{\sum V_{a}}{V_{t}}\right]
$$

Keterangan :

$\mathrm{k}$ : Banyaknya atribut/pertanyaan. 
$\mathrm{V}_{\mathrm{a}}$ : Varian/Ragam setiap pertanyaan.

$\mathrm{V}_{\mathrm{t}}$ : Varian/Ragam total (total : penjumlahan skor dari setiap pertanyaan).

○ Rumus K-R.21

$r_{11}=\left[\frac{k}{k-1}\right]\left[1-\frac{M(k-M)}{k V_{t}}\right]$

$\mathrm{k}$ : Banyaknya atribut/pertanyaan.

$M$ : Rata-rata skor setiap pertanyaan.

$\mathrm{V}_{\mathrm{t}}$ : Varian/ Ragam total (total : penjumlahan skor dari setiap pertanyaan).

Instrumen penelitian dikatakan reliable apabila nilai Cronbach's Alpha lebih besar dari pada 0.5 .

Walaupun uji reliabilitas dan validitas terlihat memiliki konsep yang berbeda, namun pada dasarnya kedua hal tersebut saling berhubungan. Beberapa hal yang menunjukkan hubungan tersebut adalah :

- Pengukuran tidak reliabel dan juga tidak valid. Dalam hal ini yang dimaksudkan adalah terkadang pengukuran yang dilakukan adalah benar atau valid namun apabila dilakukan pengukuran ulang pada waktu dan kesempatan lainnya, maka hasilnya berbeda.

- Pengukuran reliabel namun tidak valid. Dalam hal ini, proses pengukuran dilakukan secara konsisten dengan menggunakan konsep yang tidak tepat sehingga reliabilitas data dapat tercapai namun penilaian tidak valid.

- Pengukuran valid namun tidak reliable. Hal ini bisa jadi disebabkan oleh adanya pertanyaan yang ambigu sehingga menimbulkan multi-persepsi, bahasa maupun budaya respondents yang berbeda, atau pertanyaan yang kemungkinan bisa berubah jawabannya disebabkan oleh waktu.

- Pengukuran valid dan reliable. Hasil ini adalah tujuan utama pada sebuah penelitian. Sehingga diperlukan proses identifikasi pengukuran yang akurat dan sesuai dengan obyek penelitian, serta memiliki hasil yang sama meskipun pada wktu yang berbeda.

\section{Metode Penelitian}

Dari data yang diperoleh akan dilakukan analisis peramalan untuk meramalkan pendapatan Laboratorium Pengujian PPSDM MIGAS 12 periode ke depan. Alat bantu yang digunakan dalam analisis tersebut adalah Minitab 18 dan Eviews 9.

Langkah-langkah analisis data yang digunakan yaitu sebagai berikut :

1. Menyiapkan data pendapatan Laboratorium Pengujian PPSDM MIGAS.

2. Melakukan Uji Stasioneritas dalam varian dan mean.

3. Jika data tidak stasioner dalam varian maka perlu dilakukan transformasi Box-Cox terhadap data. Jika data tidak stasioner dalam mean maka perlu dilakukan differensiasi terhadap data dan dilakukan uji Augmented Dickey Fuller kembali sampai data stasioner dalam mean. 
4. Menentukan Model ARIMA

Apabila data telah stasioner dalam varian dan mean, maka langkah selanjutnya menentukan model ARIMA Box-Jenkins, mengestimasi parameter model, menguji signifikansi parameter dan verifikasi dengan Uji White Noise dan Uji Asumsi Normalitas pada residual.

5. Model Terbaik

Pemilihan model terbaik dapat ditentukan dengan melihat signifikansi parameter, independensi residual, normalitas residual, dan nilai MSE yang paling kecil.

6. Peramalan (Forecasting)

Melakukan peramalan menggunakan model terbaik.

Dari data kuisioner yang diperoleh akan dilakukan Uji Validitas dan Reliabilitas kuisioner Indeks kepuasan Masyarakat atas pelayanan Laboratorium Pengujian PPSDM MIGAS. Alat bantu yang digunakan dalam analisis tersebut adalah SPSS 23.

Langkah-langkah analisis data yang digunakan yaitu sebagai berikut :

1. Menyiapkan data hasil kuisioner IKM terhadap pelayanan Laboratorium Pengujian PPSDM Migas .

2. Uji Validitas

Uji validitas bertujuan untuk mengetahui apakah alat ukur yang dipakai dapat mengukur variabel yang seharusnya diukur. Apabila variabelnya tidak valid maka harus dihapuskan.

3. Uji Reliabilitas

Uji reliabilitas bertujuan untuk menunjukkan konsistensi suatu alat ukur/kuisioner dalam mengukur gejala yang sama.

\section{Hasil Penelitian dan Pembahasan}

\section{A. Peramalan}

\section{Pemilihan Model}

Setelah data telah stasioner dalam varian maupun mean, maka langkah selanjutnya yaitu identifikasi model. Dalam pendugaan model digunakan plot Autocorrelation Function (ACF) dan Partial Autocorrelation Function (PACF) data inflasi. Fungsi autokorelasi digunakan untuk menentukan orde q pada MA(q). Sedangkan fungsi autokorelasi parsial digunakan untuk menentukan orde $p$ pada $A R(p)$. Apabila data tidak mengalami differencing, maka d bernilai 0. Jika data stasioner setelah differencing ke-1 maka d bernilai 1 dan seterusnya. 


\section{a. Plot ACF}

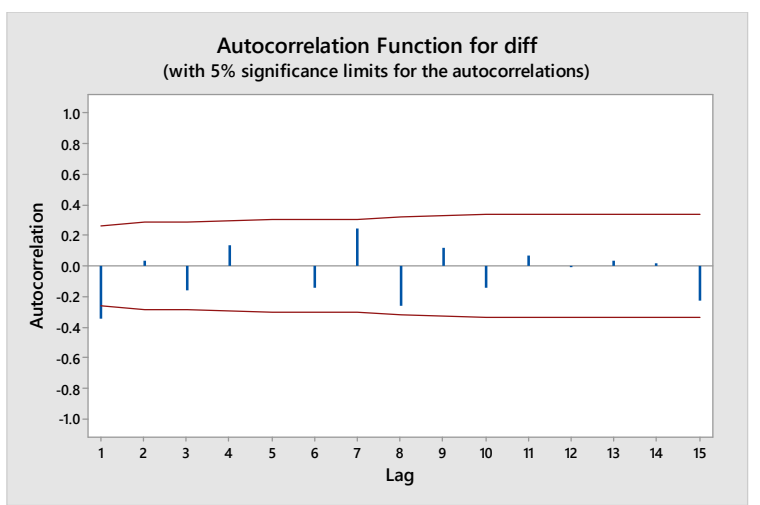

Gambar 1. Plot Autokorelasi dari data Pendapatan Laboratorium Pengujian PPSDM Migas dari Bulan Januari 2016 sampai dengan Bulan Desember 2020 setelah dilakukan transformasi 2 dan Differencing

Berdasarkan plot ACF pada output e-views, dapat dilihat bahwa plot ACF terpotong pada lag 1 atau talls off pada lag 1 . Sehingga diperoleh model yang memungkinkan yaitu IMA $(1,1)$ karena data mengalami difference satu kali.

\section{b. Plot PACF}

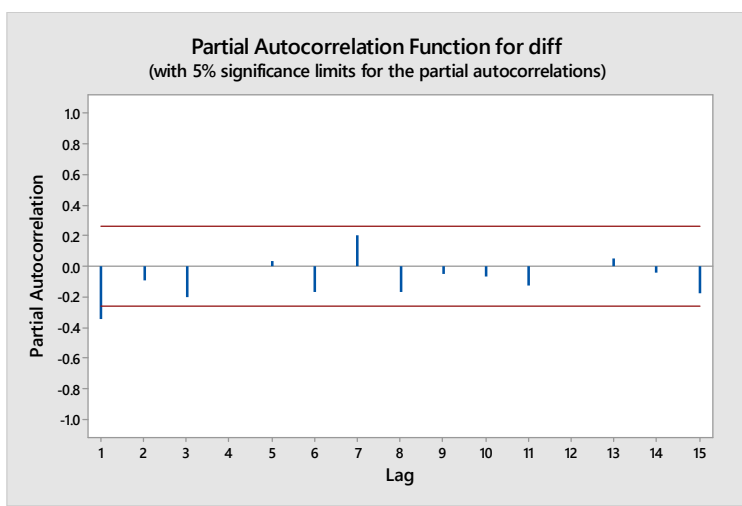

Gambar 2. Plot Autokorelasi Parsial dari data Pendapatan Laboratorium Pengujian PPSDM Migas dari Bulan Januari 2016 sampai dengan Bulan Desember 2020 setelah dilakukan transformasi 2 dan Differencing

Berdasarkan plot PACF pada output e-views, dapat dilihat bahwa plot PACF terpotong pada lag 1 atau talls off pada lag 1 . Sehingga diperoleh model yang memungkinkan yaitu $\operatorname{ARI}(1,1)$ karena data mengalami difference satu kali.

Berdasarkan plot ACF dan PACF, model yang mungkin terbentuk adalah :

\section{a. $\operatorname{ARIMA}(1,1,0)$ atau $A R I(1,1)$}

Berdasarkan plot PACF didapatkan model $A R(1)$ sehingga derajat $\mathrm{p}=1$. Setelah dilakukan uji stasioner dalam mean, perlu dilakukan difference satu kali sehingga derajat $d=1$. Dan berda- 
sarkan plot $A C F$ didapatkan model $M A(0)$ sehingga $q=0$. Maka untuk model $\operatorname{ARIMA}(p, d, q)$ yang terbentuk $\operatorname{ARIMA}(1,1,0)$.

\section{b. $\operatorname{ARIMA}(0,1,1)$ atau $\operatorname{IMA}(1,1)$}

Berdasarkan plot PACF didapatkan model $A R(0)$ sehingga derajat $\mathrm{p}=0$. Setelah dilakukan uji stasioner dalam mean, perlu dilakukan difference satu kali sehingga derajat $d=1$. Dan berdasarkan plot ACF didapatkan model MA(1) sehingga $q=1$. Maka untuk model $\operatorname{ARIMA}(p, d, q)$ yang terbentuk $\operatorname{ARIMA}(0,1,1)$.

\section{C. $\operatorname{ARIMA}(1,1,1)$}

Berdasarkan plot PACF didapatkan model $A R(1)$ sehingga derajat $\mathrm{p}=1$. Setelah dilakukan uji stasioner dalam mean, perlu dilakukan difference satu kali sehingga derajat $d=1$. Dan berdasarkan plot ACF didapatkan model MA(1) sehingga $q=1$. Maka untuk model $\operatorname{ARIMA}(p, d, q)$ yang terbentuk $\operatorname{ARIMA}(1,1,1)$.

\section{Estimasi Parameter}

Estimasi parameter dilakukan setelah beberapa model yang telah diketahui melalui identifikasi model. Kemudian, parameter-parameter tersebut diuji signifikansi terhadap masing-masing model dengan uji t-statistics.

Tabel 2. Final Estimates of Parameter

\begin{tabular}{|c|c|c|c|c|c|}
\hline No. & Model & Parameter & $\begin{array}{l}\text { Koefisien } \\
\text { Parameter }\end{array}$ & t-hitung & p-value \\
\hline \multicolumn{6}{|c|}{ Dengan Konstanta } \\
\hline \multirow[t]{2}{*}{1} & $\operatorname{ARIMA}(1,1,0)$ atau $\operatorname{ARI}(1,1)$ & AR 1 & -0.353 & -2.85 & 0.006 \\
\hline & & Constant & 0.309 & 1 & 0.321 \\
\hline \multirow[t]{2}{*}{2} & $\operatorname{ARIMA}(0,1,1)$ atau $\operatorname{IMA}(1,1)$ & MA 1 & 0.429 & 3.59 & 0.001 \\
\hline & & Constant & 0.227 & 1.3 & 0.197 \\
\hline \multirow[t]{3}{*}{3} & ARIMA $(1,1,1)$ & AR 1 & 0.132 & 0.44 & 0.66 \\
\hline & & MA 1 & 0.543 & 2.14 & 0.037 \\
\hline & & Constant & 0.195 & 1.39 & 0.171 \\
\hline \multicolumn{6}{|c|}{ Tanpa Konstanta } \\
\hline 4 & $\operatorname{ARIMA}(1,1,0)$ atau $\operatorname{ARI}(1,1)$ & AR 1 & -0.34 & -2.76 & 0.008 \\
\hline 5 & $\operatorname{ARIMA}(0,1,1)$ atau $\operatorname{IMA}(1,1)$ & MA 1 & 0.389 & 3.22 & 0.002 \\
\hline \multirow[t]{2}{*}{6} & \multirow[t]{2}{*}{ ARIMA $(1,1,1)$} & AR 1 & 0.047 & 0.14 & 0.89 \\
\hline & & MA 1 & 0.43 & 1.4 & 0.166 \\
\hline
\end{tabular}




\section{Uji Signifikansi Parameter}

Hipotesis :

$\mathrm{H}_{0}: \phi_{-} \mathrm{i}=0$ (Parameter tidak signifikan terhadap model)

$\mathrm{H}_{1}: \phi_{-} \mathrm{i} \neq 0$ (Parameter signifikan terhadap model)

Taraf Signifikansi

$\alpha=\% 5$

Daerah Kritis

Tolak $\mathrm{HO}$ jika nilai $\mathrm{p}$-value $<\alpha$.

Tabel 3. Uji Signifikansi Parameter

\begin{tabular}{|c|c|c|c|}
\hline Model & Parameter & p-value & Keputusan \\
\hline \multicolumn{4}{|l|}{ Tanpa Konstanta } \\
\hline $\operatorname{ARIMA}(1,1,0)$ atau $\operatorname{AR}(1,1)$ & $\mathrm{AR}(1)$ & 0,008 & $\mathrm{H}_{0}$ ditolak \\
\hline $\operatorname{ARIMA}(0,1,1)$ atau $M A(1,1)$ & $\mathrm{MA}(1)$ & 0,002 & $\mathrm{H}_{0}$ ditolak \\
\hline \multirow[t]{2}{*}{$\operatorname{ARIMA}(\mathbf{1}, \mathbf{1}, \mathbf{1})$} & $\mathrm{AR}(1)$ & 0,890 & $\mathrm{H}_{0}$ diterima \\
\hline & $\mathrm{MA}(1)$ & 0,166 & $\mathrm{H}_{0}$ diterima \\
\hline \multirow[t]{2}{*}{$\operatorname{ARIMA}(1,1,0)$ atau $\operatorname{AR}(1,1)$} & $\mathrm{AR}(1)$ & 0,006 & $\mathrm{H}_{0}$ ditolak \\
\hline & Constant & 0,321 & $\mathrm{H}_{0}$ diterima \\
\hline \multicolumn{4}{|l|}{ Dengan Konstanta } \\
\hline \multirow[t]{2}{*}{$\operatorname{ARIMA}(0,1,1)$ atau $M A(1,1)$} & $\mathrm{MA}(1)$ & 0,001 & $\mathrm{H}_{0}$ ditolak \\
\hline & Constant & 0,197 & $\mathrm{H}_{0}$ diterima \\
\hline \multirow[t]{3}{*}{$\operatorname{ARIMA}(\mathbf{1}, \mathbf{1}, \mathbf{1})$} & $\mathrm{AR}(1)$ & 0,660 & $\mathrm{H}_{0}$ diterima \\
\hline & $\mathrm{MA}(1)$ & 0,037 & $\mathrm{H}_{0}$ ditolak \\
\hline & Constant & 0,171 & $\mathrm{H}_{0}$ diterima \\
\hline $\operatorname{ARIMA}(0,1,1)$ atau $M A(1,1)$ & $\mathrm{MA}(1)$ & 0,001 & $\mathrm{H}_{0}$ ditolak \\
\hline
\end{tabular}

Pada taraf signifikansi $5 \%$ daapat diambil kesimpulan bahwa parameter $\operatorname{ARIMA}(1,1,0)$ dan $\operatorname{ARIMA}(0,1,1)$ tanpa konstata adalah signifikan.

Dalam pemilihan model terbaik harus memenuhi syarat tertentu, yaitu koefisien parameter signifikan terhadap model, residual berdistribusi normal, tidak ada korelasi residual antar lag, dan memiliki nilai MSE terkecil. Hasil perbandingan model yang diperoleh sebagai berikut:

Tabel 4. Pemilihan Model Terbaik

\begin{tabular}{|l|l|l|l|l|c|}
\hline Model & Persamaan Model & $\begin{array}{c}\text { Signifikansi } \\
\text { Parameter }\end{array}$ & $\begin{array}{c}\text { Independensi } \\
\text { Residual }\end{array}$ & MSE & $\begin{array}{c}\text { Normalitas } \\
\text { Residual }\end{array}$ \\
\hline Dengan Konstanta & & Tidak Signifikan & Independen & 5.61759 & Normal \\
ARIMA(1,1,0) & & & & \\
\hline
\end{tabular}




\begin{tabular}{|c|c|c|c|c|}
\hline $\begin{array}{l}\operatorname{ARIMA}(\mathbf{0}, \mathbf{1}, \mathbf{1}) \\
\operatorname{IMA}(\mathbf{1}, \mathbf{1})\end{array}$ & Tidak Signifikan & Independen & 5.48335 & Tidak Normal \\
\hline $\operatorname{ARIMA}(\mathbf{1}, \mathbf{1}, \mathbf{1})$ & Tidak Signifikan & Independen & 5.57360 & Normal \\
\hline \multicolumn{5}{|l|}{ Tanpa Konstata } \\
\hline $\begin{array}{l}\operatorname{ARIMA}(1,1,0) \\
\operatorname{ARI}(1,1)\end{array}$ & Signifikan & Independen & 5.61929 & Normal \\
\hline $\begin{array}{l}\operatorname{ARIMA}(\mathbf{0}, \mathbf{1}, \mathbf{1}) \\
\operatorname{IMA}(\mathbf{1}, \mathbf{1})\end{array}$ & Signifikan & Independen & 5.53936 & Tidak Normal \\
\hline $\operatorname{ARIMA}(1,1,1)$ & Tidak Signifikan & Independen & 5.63652 & Tidak Normal \\
\hline
\end{tabular}

Berdasarkan output diatas, dapat diperoleh bahwa model terbaik adalah $\operatorname{ARIMA}(1,1,0)$ atau $A R I(1,1)$. Karena memenuhi parameter yang signifikan, residual independen, memiliki nilai MSE yang kecil dan residual berdistribusi normal. Jadi dari kiteria tersebut dapat disimpulkan bahwa model $\operatorname{ARIMA}(1,1,0)$ atau $A R I(1,1)$ adalah model terbaik dengan persamaan :

$Z_{-} t=0.660 Z_{-}(t-1)+0.340 Z_{-}(t-2)+a_{-} t$

\section{Hasil Peramalan (Forecasting)}

Berdasarkan hasil analisis diperoleh model terbaik $\operatorname{ARIMA}(1,1,0)$ atau $A R I(1,1)$. Dari model tersebut dilakukan peramalan pendapatan Laboratorium Pengujian PPSDM Migas untuk 12 periode kedepan dengan hasil sebagai berikut :

Tabel 5. Hasil Peramalan Pendapatan Laboratorium Pengujian PPSDM Migas

\begin{tabular}{|l|c|}
\hline \multicolumn{1}{|c|}{ Periode } & Hasil Peramalan \\
\hline Januari 2021 & 22.38344 \\
\hline Februari 2021 & 22.48132 \\
\hline Maret 2021 & 22.448 \\
\hline April 2021 & 22.45934 \\
\hline Mei 2021 & 22.45548 \\
\hline Juni 2021 & 22.4568 \\
\hline Juli 2021 & 22.45635 \\
\hline Agustus 2021 & 22.4565 \\
\hline September 2021 & 22.45645 \\
\hline Oktober 2021 & 22.45647 \\
\hline November 2021 & 22.45646 \\
\hline Desember 2021 & 22.45646 \\
\hline
\end{tabular}

Data peramalan di atas merupakan data hasil transformasi Box-Cox, data telah ditransformasi dengan menggunakan transformasi sqrt(Zt) sebanyak dua kali. Data harus dikembalikan ke data awal dengan cara forecasting dipangkatkan 4. Sehingga berdasarkan data awal diramalkan Pendapatan Laboratorium Pengujian PPSDM Migas untuk 12 periode ke depan didapatkan hasil peramalan sebagai berikut: 
Tabel 7. Hasil Peramalan Pendapatan Laboratorium Pengujian PPSDM Migas setelah dikembalikan ke Bentuk Awal

\begin{tabular}{|l|c|c|}
\hline Periode & Data & $\begin{array}{c}\text { Data dalam } \\
\text { Ribuan }\end{array}$ \\
\hline Januari 2021 & 251020 & 251020000 \\
\hline Februari 2021 & 255439 & 255439000 \\
\hline Maret 2021 & 253928 & 253928000 \\
\hline April 2021 & 254442 & 254442000 \\
\hline Mei 2021 & 254267 & 254267000 \\
\hline Juni 2021 & 254326 & 254326000 \\
\hline Juli 2021 & 254306 & 254306000 \\
\hline Agustus 2021 & 254313 & 254313000 \\
\hline September 2021 & 254311 & 254311000 \\
\hline Oktober 2021 & 254311 & 254311000 \\
\hline November 2021 & 254311 & 254311000 \\
\hline Desember 2021 & 254311 & 254311000 \\
\hline
\end{tabular}

\section{B. Uji Validitas dan Realibilitas Indeks Kepuasan Masyarakat}

Uji Validitas

$>\quad$ Hipotesis

HO : Butir pertanyaan tidak valid

H1 : Butir pertanyaan valid

$>\quad$ Taraf signifikansi : $\alpha=5 \%$

$>\quad$ Statistik Uji

Dilihat dari output correlation, diperoleh hasil:

Tabel 8. Uji Validitas

\begin{tabular}{|c|c|c|c|c|c|}
\hline \multicolumn{6}{|c|}{ Correlations } \\
\hline & & $\mathrm{X} 7$ & X8 & X9 & X_TOTAL \\
\hline \multirow[t]{3}{*}{$\mathrm{X} 1$} & Pearson Correlation &.$^{\mathrm{a}}$ &.$^{\mathrm{a}}$ &.$^{\mathrm{a}}$ &.$^{\mathrm{a}}$ \\
\hline & Sig. (2-tailed) & . & . & . & . \\
\hline & $\mathrm{N}$ & 108 & 108 & 108 & 108 \\
\hline \multirow[t]{3}{*}{$\mathrm{X} 2$} & Pearson Correlation &.$^{\mathrm{a}}$ &.$^{\mathrm{a}}$ &.$^{a}$ &.$^{\mathrm{a}}$ \\
\hline & Sig. (2-tailed) & . & . & . & . \\
\hline & $\mathrm{N}$ & 108 & 108 & 108 & 108 \\
\hline \multirow[t]{3}{*}{ X3 } & Pearson Correlation & $.741^{* *}$ & -.120 & .189 & $.936^{* *}$ \\
\hline & Sig. (2-tailed) & .000 & .218 & .050 & .000 \\
\hline & $\mathrm{N}$ & 108 & 108 & 108 & 108 \\
\hline
\end{tabular}




\begin{tabular}{|c|c|c|c|c|c|}
\hline \multirow[t]{3}{*}{$X 4$} & Pearson Correlation & $.351^{* *}$ & .060 & -.189 & $.670^{* *}$ \\
\hline & Sig. (2-tailed) & .000 & .539 & .050 & .000 \\
\hline & $\mathrm{N}$ & 108 & 108 & 108 & 108 \\
\hline \multirow[t]{3}{*}{ X5 } & Pearson Correlation & $.741^{* *}$ & -.120 & .189 & $.936^{* *}$ \\
\hline & Sig. (2-tailed) & .000 & .218 & .050 & .000 \\
\hline & $\mathrm{N}$ & 108 & 108 & 108 & 108 \\
\hline \multirow[t]{3}{*}{ X6 } & Pearson Correlation & $.351^{* *}$ & .060 & -.189 & $.670^{* *}$ \\
\hline & Sig. (2-tailed) & .000 & .539 & .050 & .000 \\
\hline & $\mathrm{N}$ & 108 & 108 & 108 & 108 \\
\hline \multirow[t]{3}{*}{ X7 } & Pearson Correlation & 1 & $-.196^{*}$ & .080 & $.787^{* *}$ \\
\hline & Sig. (2-tailed) & & .042 & .410 & .000 \\
\hline & $\mathrm{N}$ & 108 & 108 & 108 & 108 \\
\hline \multirow[t]{3}{*}{$\mathbf{X 8}$} & Pearson Correlation & $-.196^{*}$ & 1 & -.181 & -.046 \\
\hline & Sig. (2-tailed) & .042 & & .061 & .635 \\
\hline & $\mathrm{N}$ & 108 & 108 & 108 & 108 \\
\hline \multirow[t]{3}{*}{ X9 } & Pearson Correlation & .080 & -.181 & 1 & $.270^{* *}$ \\
\hline & Sig. (2-tailed) & .410 & .061 & & .005 \\
\hline & $\mathrm{N}$ & 108 & 108 & 108 & 108 \\
\hline \multirow{3}{*}{$\begin{array}{l}\text { X_TO- } \\
\text { TÁL }\end{array}$} & Pearson Correlation & $.787^{* *}$ & -.046 & $.270^{* *}$ & 1 \\
\hline & Sig. (2-tailed) & .000 & .635 & .005 & \\
\hline & $\mathrm{N}$ & 108 & 108 & 108 & 108 \\
\hline
\end{tabular}

Pada taraf signifikansi $5 \%$ untuk setiap butir pertanyaan 1 sampai butir pertanyaan 9 (X1, X2, X3, X4, X5, X6, X7, X8, dan X9) dapat disimpulkan bahwa H0 ditolak untuk X3, X4, X5, X6, X7 dan $X 9$. Jadi untuk butir pertanyaan $X 3, X 4, X 5, X 6, X 7$ dan $X 9$ valid.

\section{Uji Reliabilitas IKM}

Indikator tersebut dikatakan reliabel apabila nilai alpha $>0.6$ atau $>0.5$

Tabel 9. Uji Reliabilitas

\begin{tabular}{|l|c|}
\hline \multicolumn{2}{|c|}{ Reliability Statistics } \\
\hline Cronbach's Alpha & N of Items \\
\hline .747 & 9 \\
\hline
\end{tabular}

Dari output diatas diperoleh nilai alpha 0.747. Sehingga dapat disimpulkan bahwa Indikator semua butir pertanyaan yang valid reliabel karena nilai alpha $=0.747>0.5$.

\section{Kesimpulan}

Setelah dilakukan analisis mengenai Penerimaan Laboratotium Pengujian PPDM Migas untuk 12 periode ke depan menggunakan ARIMA Box-Jenkins, diperoleh kesimpulan sebagai berkut: 
1. Berdasarkan time series plot dapat disimpulkan bahwa data penerimaan Laboratorium Pengujian PPSDM Migas yang telah direkam tiap bulan dari bulan Januari tahun 2016 sampai dengan bulan Desember 2020 membentuk pola trend naik dan tidak ada indikasi musiman, sehingga data tersebut memenuhi syarat untuk dapat dianalisis menggunakan metode ARIMA Box-Jenkins. Model ARIMA terbaik untuk pemodelan pendapatan Laboratorium Pengujian PPSDM Migas adalah $\operatorname{ARIMA}(1,1,0)$ atau $A R I(1,1)$. Berdasarkan pemodelan runtun waktu tersebut, maka nilai hasil peramalan dengan jumlah Rp3.049.285.000,00 untuk Penerimaan Laboratorium Pengujian PPSDM Migas mulai bulan Januari 2021 sampai dengan Desember 2021. Jumlah tersebut lebih tinggi dibandingkan dengan tahuntahun sebelumnya.

2. Dalam kuisioner yang disebar oleh Laboratorium Pengujian PPSDM Migas, ada beberapa butir pertanyaan yang tidak valid, walaupun reliable. Jika dilakukan penghapusan butir pertanyaan dalam kuisioner yang tidak valid, hasilnya akan valid dan reliable.

\section{Daftar Pustaka}

Pemerintah Indonesia. 2017. Undang-Undang Nomor 14 Tahun 2017 tentang Peraturan Menteri Perdayagunaan Aparatur Negara dan Reformasi Birokrasi Indonesia. Jakarta : Sekretariat Negara.

PPSDM Migas. 2021. https://ppsdmmigas.esdm.go.id/id/. Cepu

Soejoeti, Z. 1987. Analisis Runtun Waktu . Jakarta: Karunia.

Susanto, F. 2009. Forecasting Volume Penjualan Produk Kertas Perusahaan. PT. Pura Barutama dengan menggunakan Analisisi Runtun Waktu dan Program Minitab. Universitas Negeri Semarang.

Yudiasaputro, H. 2020. Teori Uji Validitas dan Reliabilitas. https://berbagienergi. com/2020/04/22/teori-uji-validitas-dan-reliabilitas/. Diakses pada 26 Januari 2021. 